\title{
Staffing the dream archive A view from the other side of the reading room desk
}

A $s$ the inhabitants of academe go about their daily routines, it is important to take time to dream about how things ought to be. The ideal might not be as unattainable as you think. Historian Christopher Phelps recently outlined his vision of a "dream archive" in the January 5, 2007, issue of The Chronicle of Higher Education. Based on research trips to archival repositories at universities across the country, Phelps muses that an ideal archive would offer long operating hours, grants supporting research, a quiet environment, appropriate lighting and security, reasonably priced photocopies that can be purchased with a credit card, wi-fi access, comfortable furniture, a pleasant ambience, and creative public programming. As I went down the list I was relieved to see my department meets most of his criteria, and I imagine many archivists, curators, and special collections librarians did the same with varying degrees of satisfaction or discomfort.

My warm feeling of contentment, however, was quickly chilled as I asked myself, "Where are the archivists in the dream archive?" (I use the term archivist to collectively refer to archival professionals that include curators and special collections librarians.) Perhaps a benign oversight by Phelps, but one that is a bit disturbing to archivists who know a dream archive could not even function without a professional staff to make archival scholarship there possible. While much of historical research is solitary in nature, it is also largely dependant upon collaboration between scholars and the archivists who are responsible for preserving archival collections and supporting their use. Evidence of the contributions made by archivists to scholarly communication can be readily found in the acknowledgement sections of books and articles by historians and other scholars who recognize in print the crucial assistance they received at archival repositories.

Despite its impressive features, the dream archive would inevitably fall short of ideal without first-rate archivists to not only provide access but also guidance during the research process. With this in mind, I began to wonder what would distinguish the archivists in a dream archival facility. I concluded that just as Phelps found elements of a dream archive in several of the institutions he visited, some essential qualities of the ideal archivist are embodied in the archival professionals who work in existing archives. In my experience, the ideal archivist:

- Views supporting the use of collections as his or her top priority. The ideal archivist knows that the use of archival materials ultimately validates all of the effort that is put into acquiring, preserving, and processing them. Thus, reference service to on-site and remote researchers takes precedence over other duties. The ideal archivist also employs a proactive approach to processing collections that facilitates use by reducing the backlog of unprocessed collections that are typically inaccessible to researchers.

- Actively provides research service beyond just pulling the materials requested. Because they work with their repository's collections on a daily basis, archivists are experts on their contents and interrelationships. They usually know quite a bit about collections at other institutions, too. Creating self-sufficient users

Shan Sutton is head of special collections at the University of the Pacific, e-mail: ssutton@pacific.edu

(0) 2007 Shan Sutton 
is a worthy goal, but an archivist's knowledge is an indispensable resource that cannot be fully captured in even the best research tools. The ideal archivist recognizes this, and offers more than mere collection retrieval services by proactively giving guidance on potential sources and research strategies before, during, and after a scholar visits an archive.

The archivist-scholar interaction differs from most other reference services in that it may occur over a period of months or even years. For example, I have been working with a professor from another university over the past two years as he studies my department's Brubeck Collection in writing a book on the legendary Dave Brubeck Quartet. In addition to providing assistance in using different parts of this large (350 linear feet and growing) collection, I also keep him informed of newly acquired materials that relate to his research, such as the papers of the Brubeck Quartet's saxophonist Paul Desmond, as well as relevant items I discover as I work with the Brubeck Collection over time.
- Is flexible in the application of rules and policies. Archives inherently have lots of rules and regulations, mostly to protect the irreplaceable materials within them. The ideal archivist balances blind enforcement with a flexible consideration of circumstances. If a scholar is visiting from far away, the archivist offers to open the reading room an hour or two early each day. (The staff is usually there before public hours anyway.) If students want to use images in their class presentations, the archivist lets them take a reasonable number of snapshots with a digital camera instead of paying the standard fees for scanned images supplied by the archives. Well-meaning archivists may have different views of how much flexibility is appropriate, but the ideal archivist is willing to make exceptions to rules and policies in promoting the use of collections.

Although this brief list of an ideal archivist's fundamental traits is far from comprehensive, it serves as a reminder that the finest archival

(continues on page 602)

\section{A definitive reference dedicated to social work and social welfare}

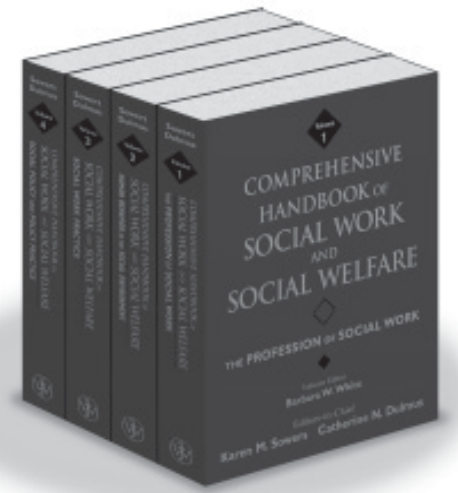

Releasing February 2008! SPECIAL INTRODUCTORY OFFERSave $\$ 100$ when you order the set by May 31, 2008!

$\$ 600.00$ introductory price through $5 / 31 / 08 ; \$ 700.00$ thereafter
The Comprehensive Handbook of Social Work and Social Welfare represents an in-depth and essential source of information on the field. Organized by major foundational areas within the social work curriculum, each volume includes cutting-edge information related to all aspects of the profession to guide practice and policy decision-making. This multivolume handbook spans the field, providing a balance of perspectives from experts in the U.S. and a diverse number of other countries.

\begin{tabular}{|c|c|}
\hline & $\begin{array}{l}\text { Volume 1: The Profession of Social Work } \\
\text { BARBARA W. WhITE, PHD, UnIVERSITY OF TEXAS, } \\
\text { AUSTIN, VolUME EDITOR } \\
978-0-471-76997-2\end{array}$ \\
\hline & $\begin{array}{l}\text { Volume 2: Human Behavior } \\
\text { in the Social Environment } \\
\text { BRUCE A. THYER, PHD, FLORIDA STATE UNIVERSITY, } \\
\text { VOLUME EDITOR } \\
978-0-471-76272-0\end{array}$ \\
\hline & $\begin{array}{l}\text { Volume 3: Social Work Practice } \\
\text { WiLliam RowE, DSW AND LISA A. RAPP-PAGLICCI, }\end{array}$ \\
\hline $\begin{array}{l}\text { INDIVIDUAL VOLUMES } \\
\text { AVAILABLE SEPARATELY }\end{array}$ & $\begin{array}{l}\text { BOTH OF UNIVERSTTY OF SOUTH FLORIDA, VOLUME EDITORS } \\
978-0-471-76280-5\end{array}$ \\
\hline $\begin{array}{l}\text { Each Volume: Hardcover } \bullet 500 \mathrm{pp} \\
\text { February } 2008 \bullet \$ 150.00 \text { introductory } \\
\text { price through } 5 / 31 / 08 ; \$ 175.00 \text { thereafter }\end{array}$ & $\begin{array}{l}\text { Volume 4: Social Policy and Policy Practice } \\
\text { Ira C. COLBY, DSW, ACSW, LCSW, UnIVERSITY } \\
\text { OF HousTON, VoluME EDITOR } \\
978-0-471-76998-9\end{array}$ \\
\hline
\end{tabular}

Wiley and the Wiley logo are registered trademarks of John Wiley \& Sons, Inc. All other trademarks are the property of their respective owners. 


\section{New York University (NYU) and the Palmer}

School of Library and Information Science at Long Island University have been awarded $\$ 700,133$ in federal funds for their dual-degree scholar-librarian program. The program prepares students for careers in academic institutions, research institutes, cultural organizations, and other research settings by conferring two master's degrees-one from NYU's Graduate School of Arts and Science and one in library and information science from the Palmer School. The grant from the Laura Bush 21st Century Librarian Program of the Institute of Library and Museum Services will provide scholarships of $\$ 480,000$ over the next three years.

The Johns Hopkins University has been awarded $\$ 476,000$ to collaborate with the Baltimore-based Afro-American Newspapers to open the 115-year-old newspaper company's historic archives to access by scholars and others. The Andrew W. Mellon Foundationfunded project will involve the university's Center for Africana Studies in the Krieger School of Arts and Sciences and the Center for Educational Resources at the Sheridan Libraries. Founded in 1892 by John Murphy Sr., a former slave, the Afro is the nation's longest running family-owned African American weekly newspaper. The archives, comprising 2,055 linear feet of boxed materials, contain a rich collection of letters, business records, journals, personal correspondence, and photographs.

\section{Acquisitions}

The papers of Jack McDevitt and of E. E. Knight have been acquired as additions to the

Ed. note: Send your news to: Grants \& Acquisitions, C\&RL News, 50 E. Huron St., Chicago, IL 60611-2795; e-mail: agalloway@ala.org.
Science Fiction and Fantasy Writers of America (SFWA) Collection in the department of Rare Books and Special Collections at Northern Illinois University (NIU). NIU is one of eleven SFWA repositories across the United States receiving books nominated for the Nebula Award through the SFWA circulating book program. McDevitt is the author of 14 novels and numerous short stories, and is the winner of the 2007 Nebula Award for his novel Seeker. Knight, an NIU alumnus, is the author of the Vampire Earth Series and the Age of Fire Series. Both collections contain early drafts, uncorrected proofs, and some unpublished materials from the authors.

The papers of Meyer Schapiro (1904-96) educator, art critic, and professor of fine arts have been acquired by Columbia University's Rare Book \& Manuscript Library. Schapiro began teaching art history at Columbia in 1928, becoming a full professor in 1952 . He was named university professor, Columbia's highest rank, in 1965 and became university professor emeritus in 1973. The Meyer Schapiro papers are composed primarily of drafts of lectures, manuscripts, and published and unpublished articles. Also included in the collection is substantial correspondence with family members, arts institutions, and other artists and intellectuals. $n$

("Staffing the dream" continued from page 591)

repositories not only have well-appointed reading rooms with thoughtful policies, they are also distinguished by user-focused archivists who are active participants in the research process. When the archivist-researcher relationship is at its best, new insights seem to pop out of every box that is brought from the stacks, and the documentary puzzle pieces fall into place. This kind of archival alchemy is surely a phenomenon that would regularly occur in the dream archive. $n$ 